\title{
Evaluation of Nile tilapia in monoculture and polyculture with giant freshwater prawn in biofloc technology system and in recirculation aquaculture system
}

\author{
Hamilton Hisano • Phillipe T. L. Barbosa • Liliam A. Hayd • \\ Cristiano C. Mattioli
}

Received: 29 May 2019/Accepted: 17 October 2019/Published online: 30 October 2019

(C) The Author(s) 2019

\begin{abstract}
Biofloc technology system (BFT), recirculation aquaculture system (RAS) and polyculture promote efficient use of water, area and nutrient recycling, which are essential practices for sustainable aquaculture development. The aim of this study was to evaluate the growth, feed efficiency, biofloc composition and water quality of Nile tilapia Oreochromis niloticus (Linnaeus, 1758) in monoculture and polyculture with giant freshwater prawn Macrobrachium rosenbergii (De Man, 1906) in BFT and RAS, over a period of 30 days. Fish $(n=128 ; 7.29 \pm 0.67 \mathrm{~g})$ were distributed randomly in 16 experimental tanks ( 8 fish/tank). Prawn $(n=96 ; 0.50 \pm 0.09 \mathrm{~g})$ were allocated in 8 experimental tanks $(12$ prawn/tank $)$ in a polyculture. The experimental design was completely randomized with four treatments with four replicates each, in a factorial design $2 \times 2$ (BFT and RAS vs. monoculture and polyculture). The experimental diet (28\% of digestible protein; $3100 \mathrm{kcal} \mathrm{kg}^{-1}$ of digestible energy) was used both to fish and prawn in BFT and RAS. There was significant effect $(p<0.01)$ of the system and the culture for weight gain, apparent feed conversion and protein efficiency ratio. The average weight gain and apparent feed conversion of tilapia in monoculture (30.04 $\mathrm{g}$ and 1.39) and in polyculture (36.44 $\mathrm{g}$ and 1.27) were superior $(p<0.01)$ in BFT than in monoculture (23.64 $\mathrm{g}$ and 1.74) and in polyculture (24.14 $\mathrm{g}$ and 1.61) in RAS. Weight gain and survival of giant freshwater prawn was superior $(p<0.01)$ in BFT $(0.43 \mathrm{~g}$ and $87 \%)$ compared to RAS $(0.26 \mathrm{~g}$ and $79 \%)$. The data showed that BFT provides better growth performance responses in monoculture for Nile tilapia and in polyculture with giant freshwater prawn compared to RAS.
\end{abstract}

Keywords Aquaculture $\cdot$ Biofloc $\cdot$ Heterotrophic microorganisms $\cdot$ Prawn $\cdot$ Tilapia

\section{Introduction}

According to Food and Agriculture Organization of the United Nations (FAO), aquaculture has grown faster than other major food production sectors, and its expansion aimed at meeting the increase of world fish demand, and preserving natural fish stocks (FAO 2018a). Currently, to produce fish in quantity and quality requires reduction of the environmental impact from aquaculture, through the improvement of culture systems (Robinson et al. 2018).

H. Hisano $(\bowtie) \cdot$ C. C. Mattioli

Embrapa Meio Ambiente, Rodovia SP 340, Km 127,5, C.P. 69, Jaguariúna, SP 13918-110, Brazil

e-mail: hamilton.hisano@embrapa.br

P. T. L. Barbosa - L. A. Hayd

Universidade Estadual de Mato Grosso do Sul, Unidade de Aquidauana, Aquidauana, MS, Brazil 
The biofloc technology system (BFT) provides the intensive aquaculture with no or minimum water renewal reducing its environmental impact (Poli et al. 2019). In this system, the management of the microbial community is determinant to keep the water quality, especially the development of heterotrophic bacteria, through the complementary carbon source, which stimulates its growth and improves the process of removing inorganic nitrogen from water, besides allowing its transformation into bacterial biomass (Avnimelech 2007; Robinson et al. 2019). In this process, the efficiency of heterotrophic bacteria exceeds that of autotrophic nitrifying bacteria, which are also present in BFT (Vargas-Albores et al. 2019).

Bioflocs have high nutritional characteristics with protein content between 28 and $40 \%$ (Azim and Little 2008), and adequate balance of amino acids, fatty acids, minerals and vitamins (Crab et al. 2012). Therefore, bioflocs are considered a complementary feed source for Nile tilapia Oreochromis niloticus (Linnaeus, 1758) and giant freshwater prawn Macrobrachium rosenbergii (De Man, 1906) (Haque et al. 2015). According to Avnimelech and Kochba (2009), tilapia can assimilate the biofloc protein, meeting up to $25 \%$ of their nutritional requirements, emphasizing the contribution of the natural feed as a source of high biological value, allowing the reduction of protein levels in feed (De-Schryver et al. 2008; Luo et al. 2014).

Recirculation aquaculture system (RAS) is a technology based on the water recycling using mechanical and biological filters which allows the production of various aquaculture species at high densities (Bregnballe 2015). Thus, RAS can be considered an effective technology that promotes sustainable basis and was used mainly to freshwater and marine fish farming (Schreier et al. 2010). However, although demonstrating positive results of growth of tilapia and giant freshwater prawn in RAS (Luo et al. 2014; Ballester et al. 2017), operating and implementation costs of all structure are considered high. For tilapia culture, BFT was more effective in terms of cost-benefit than RAS (Luo et al. 2014).

Tilapia is the second main species cultured in the world, and the common carp Cyprinus carpio (Linnaeus, 1758) is the first one (FAO 2018a). Future prospects indicate that in a few decades, tilapia will become the main species of world aquaculture, since it is widely cultivated in tropical and subtropical regions (Tacon et al. 2011). Some characteristics that make it widely known in the world are rusticity, omnivorous habit, rapid growth and excellent meat quality (Grassi et al. 2016). Moreover, giant freshwater prawn has a consolidated and expanding production chain (FAO 2018b) due to its adaptability, rapid growth, resistance to disease and adaptability to polyculture with fish (Hossain and Islam 2006; Haque et al. 2018).

Polyculture is a culture system of two or more aquatic species within the same body of water (Rohmana et al. 2015), allowing fish/prawn farmers to achieve productive efficiency and superior profits (Li and Dong 2000). Moreover, fish with prawn culture improve the ecological balance of pond avoiding massive algal blooms (Uddin et al. 2006), causing less environmental impact than monoculture (Santos and Valenti 2002). Nile tilapia and giant freshwater prawn polyculture has high efficiency, because they have distinct ecological niches and consume natural feed (Zimmermann and New 2000). Thus, it is a widely used polyculture model that provides positive growth performance responses for both species using supplemental high-quality feed and keeping the water quality of the systems (García-Pérez et al. 2000; Santos and Valenti 2002; Haque et al. 2015).

The objective of this study was to evaluate the growth, feed efficiency, biofloc composition and water quality of Nile tilapia in monoculture and polyculture with giant freshwater prawn in BFT and RAS.

\section{Materials and methods}

\section{Ethical statement}

The experiment was conducted at Laboratório de Ecossistemas Aquáticos, Embrapa Meio Ambiente, Jaguariúna, SP and all experimental procedures were in accordance with the Ethical Principles in Animal Research and approved by the Committee for Ethics in Animal Experimentation at the Embrapa Meio Ambiente (Protocol: 001/2015). 
Experimental diets

The experimental diets were formulated to contain $28 \%$ of digestible protein (DP) and $3100 \mathrm{kcal} \mathrm{kg}^{-1}$ of digestible energy (DE), according to National Resource Council-NRC $(1993,2011)$ and Furuya (2010) (Table 1).

Dietary ingredients were ground in a laboratory mill (Marconi Laboratory Equipment Ltda., MA340, Piracicaba/SP-Brazil) to obtain a 0.5 -mm particle. After they were weighed, they were mixed in a Y-type vertical homogenizer (Marconi Laboratory Equipment Ltda., MA201, Piracicaba/SP-Brazil), moistened with approximately $20 \%$ water $\left(45^{\circ} \mathrm{C}\right)$ and processed into 2.5 - $\mathrm{mm}$ diameter granules through a laboratory pelletizer (GPaniz Industrial Equipment Feed Ltda., MCR-22-SS, Caxias do Sul/RS-Brazil). Diets were dried in a drying oven $\left(55^{\circ} \mathrm{C}\right.$ ) with air circulation for $24 \mathrm{~h}$ (Marconi Laboratory Equipment Ltda., MA035/1, Piracicaba/SP-Brazil) and then stored under refrigeration $\left(5^{\circ} \mathrm{C}\right)$ until its use.

Table 1 Formulation, proximate and estimated composition of experimental diets (based on dry matter)

Ingredient

\begin{tabular}{|c|c|}
\hline Soybean meal & 59.40 \\
\hline Corn & 23.05 \\
\hline Wheat middlings & 10.00 \\
\hline L-Lysine & 0.03 \\
\hline DL-Methionine & 0.37 \\
\hline L-Threonine & 0.27 \\
\hline Soybean oil & 2.36 \\
\hline Dicalcium phosphate & 3.90 \\
\hline Common salt & 0.10 \\
\hline Vit/min supplement ${ }^{\mathrm{a}}$ & 0.50 \\
\hline $\mathrm{BHT}^{\mathrm{b}}$ & 0.02 \\
\hline Total & 100.00 \\
\hline \multicolumn{2}{|c|}{ Proximate and estimated composition } \\
\hline Crude protein $(\%)^{\mathrm{d}}$ & 31.59 \\
\hline Digestible protein $(\%)^{\mathrm{c}}$ & 28.00 \\
\hline Digestible energy $\left(\mathrm{MJ} \mathrm{kg}^{-1}\right)^{\mathrm{c}}$ & 12.97 \\
\hline Ether extract $(\%)^{\mathrm{d}}$ & 3.30 \\
\hline Crude fiber $(\%)^{\mathrm{d}}$ & 3.50 \\
\hline Total Ca $(\%)^{\mathrm{c}}$ & 1.18 \\
\hline Available $\mathrm{P}(\%)^{\mathrm{c}}$ & 0.70 \\
\hline Digestible methionine $(\%)^{\mathrm{c}}$ & 0.60 \\
\hline Digestible lysine $(\%)^{\mathrm{c}}$ & 1.54 \\
\hline Digestible tryptophan $(\%)^{\mathrm{c}}$ & 0.34 \\
\hline Digestible threonine $(\%)^{\mathrm{c}}$ & 1.18 \\
\hline $\mathrm{DE}: \mathrm{PD}^{\mathrm{c}}$ & 110.70 \\
\hline Total $\mathrm{Ca} /$ available $\mathrm{P}^{\mathrm{c}}$ & 1.68 \\
\hline Mineral matter $(\%)^{\mathrm{d}}$ & 7.50 \\
\hline
\end{tabular}

${ }^{a}$ Vitamin-mineral supplement (kg of diet): selenium: $75.00 \mathrm{mg}$; copper: $2000.00 \mathrm{mg}$; choline chloride: $125.00 \mathrm{~g}$; manganese: $3750.0 \mathrm{mg}$; zinc: $20.00 \mathrm{mg}$; iron: $15.00 \mathrm{mg}$; iodine: $125.00 \mathrm{mg}$; niacin: $7800.00 \mathrm{mg}$; folic acid: $750.00 \mathrm{mg}$; pantothenic acid: $3750.00 \mathrm{mg}$; biotin: $125.00 \mathrm{mg}$; vitamin C: $53.00 \mathrm{~g}$; vitamin A: 2,000,000.00 IU; vitamin $\mathrm{D}_{3}: 500,000.00 \mathrm{IU}$; vitamin E: $15,000.00 \mathrm{IU}$; vitamin $\mathrm{K}_{3}: 1,000.00 \mathrm{mg}$; vitamin $\mathrm{B}_{1}: 2500.00 \mathrm{mg}$; vitamin $\mathrm{B}_{2}: 2500.00 \mathrm{mg}$; vitamin $\mathrm{B}_{6}: 2000.00 \mathrm{mg}$; vitamin $\mathrm{B}_{12}$ : $5000.00 \mathrm{mg}$

${ }^{\mathrm{b}}$ Butylated hydroxytoluene

${ }^{\mathrm{c}}$ Estimated values according to Furuya (2010)

${ }^{\mathrm{d}}$ Analyzed values according to AOAC (2000) 
For the purposes of control and certification (Table 1), dry matter (DM), crude protein (CP), ether extract (EE), crude fiber (CF) and mineral matter (MM) from the diet were analyzed in duplicate before the experimental trial, based on AOAC (2000). The total carbon (C) and total nitrogen (N) of sugar cane molasses were analyzed by dry combustion using an elemental analyzer CN (TruSpec CN LECO ${ }^{\circledR}$, Leco, St. Joseph, MI, USA).

\section{Experimental system}

The RAS experimental tanks (useful volume of $150 \mathrm{~L}$ ) were composed by independent recirculation system and supplementary aeration via radial air blower (1 hp/system). Air-lift biofilters (10 L) were used in RAS, according to recommendations of Ballester et al. (2017). The thermostats coupled to shielded resistance $\left(500 \mathrm{~W} /\right.$ tank) were used to keep the water temperature constant at $26.0^{\circ} \mathrm{C}$.

The development of bioflocs is an active process that depends on physical, chemical and biological factors (Gao et al. 2019). To accelerate the initial development of bioflocs in the experimental BFT tanks (150 L), $1 \mathrm{~L}$ of water from a stabilized BFT that had a balance in water quality, nitrogen compounds, flocs and heterotrophic microbial community development, and was inoculated for 10 days prior to the beginning of the experiment. The biofloc-rich water showed the following values to $\mathrm{pH}$ : 7.1 , TAN: $0.22 \mathrm{mg} \mathrm{L}^{-1}$, $\mathrm{NO}_{2}{ }^{-}: 0.47 \mathrm{mg} \mathrm{L}^{-1}$ and $\mathrm{NO}_{3}{ }^{-}: 4.2 \mathrm{mg} \mathrm{L}^{-1}$.

Growth trial

All male Nile tilapia ( $n=128 ; 7.29 \pm 0.67 \mathrm{~g})$ were individually weighed and randomly distributed in 16 experimental tanks $(150 \mathrm{~L})$ using 8 fish per tank. Giant freshwater prawns $(n=96 ; 0.50 \pm 0.09 \mathrm{~g})$ were allocated in 8 experimental tanks in a density of 12 prawns per tank in a polyculture treatment. The photoperiod used was 12-h light:12-h dark.

The experimental design was completely randomized in a factorial design $2 \times 2$ (BFT and RAS vs. monoculture and polyculture) with four replications per treatment. During the experimental period, sugar cane molasses were added as a source of carbon at ratio of $12: 1(\mathrm{C}: \mathrm{N})$ and was added when required based on TAN, C:N ratio and total carbon of molasses (Samocha et al. 2007; Avnimelech 2009; Schveitzer et al. 2013). RAS was siphoned when necessary to keep the water quality. During the trial, water was not renewed in BFT. The $\mathrm{C}$ and $\mathrm{N}$ of sugarcane molasses used in this trial were, respectively, (\%) C: $35.49 \pm 0.49$ and $\mathrm{N}: 0.29 \pm 0.01$.

During the experimental period, the animals were fed three times a day until apparent satiety: at 8 a.m., at 12 p.m., and at 4 p.m., over a period of 30 days. At the end of the growth trial, fish and prawn were fasted for $24 \mathrm{~h}$ before being anesthetized $\left(70 \mathrm{mg} \mathrm{L}^{-1}\right.$ of benzocaine) and individually weighed. The growth variables evaluated to tilapia were: weight gain [WG $(\mathrm{g})=$ final weight $(\mathrm{g})$ - initial weight $(\mathrm{g})]$; feed intake [FI $(\mathrm{g})=$ feed intake $(\mathrm{g})]$; apparent feed conversion $[\mathrm{AFC}=$ feed intake $(\mathrm{g}) /$ weight gain $(\mathrm{g})]$; specific growth rate $(\operatorname{SGR}(\%$ day-1) $=100 \times[\ln$ final weight $(\mathrm{g})-\ln$ initial weight $(\mathrm{g}) /$ experimental period $])$; protein efficiency ratio $[$ PER $(\%)=100 \times($ weight gain $(\mathrm{g}) /$ crude protein intake $(\mathrm{g})]$ and survival $[\mathrm{S}(\%)=100 \times($ initial number of fish/final number of fish)]. For the giant freshwater prawn, weight gain (WG) and survival (S) were recorded.

Water quality monitoring

The water temperature $\left({ }^{\circ} \mathrm{C}\right)$, dissolved oxygen $\left(\mathrm{DO}-\mathrm{mg} \mathrm{L}^{-1}\right)$ and $\mathrm{pH}$ were measured daily using Horiba U-53 multi-probe (Horiba Advanced Technology Center Ltd., Kyoto-Japan). Nitrogen compounds were analyzed weekly. TAN was determined by the salicylate testing (method 8155, Hach $^{\circledR}$, Loveland-US), nitrite $\left(\mathrm{NO}_{2}{ }^{-}\right)$by the NitriVer ${ }^{\circledR} 2$ testing (method 8153, $\mathrm{Hach}^{\circledR}$, Loveland-US), and Nitrate $\left(\mathrm{NO}_{3}{ }^{-}\right.$) by the dimethylphenol testing (method 8158, Hach $^{\circledR}$, Loveland-US), both with the DR 2000 spectrophotometer.

In the BFT treatments, the volume of settleable solids (SS) was analyzed weekly. Samples of $1 \mathrm{~L}$ of water from each experimental unit with biofloc culture were collected and transferred to Imhoff-type cones to obtain the volume of settleable solids (SS) $\left(\mathrm{mL} \mathrm{L}^{-1}\right)$ (Avnimelech 2007). 
Statistical analysis

The results obtained for the different variables and analyses were submitted to the normality test and homogeneity of variance, followed by analysis of variance (ANOVA). When significant, Tukey's test was applied at $5 \%$. The data were analyzed in the $\mathrm{R}$ statistical program of version 3.2.5.

\section{Results}

During the experimental period, tilapia survival (S) was $100 \%$ in polyculture and $93.75 \%$ in monoculture. There was significant effect $(p<0.01)$ of the system and the culture for WG, AFC and PER. Tilapia in monoculture and in polyculture showed better WG and AFC in BFT than RAS. On the other hand, tilapia in BFT in polyculture had superior $(p<0.01) \mathrm{WG}$ and AFC when compared with tilapia in monoculture. In RAS, there were no significant differences. There were no differences for PER for tilapia in monoculture and in polyculture when compared BFT and RAS. On the other hand, comparing culture types, fish in polyculture showed superior $(p<0.01)$ PER in BFT and RAS. There was a positive interaction $(p<0.01)$ between culture (monoculture and polyculture) and systems (BFT and RAS). Considering the effect of systems, tilapia in BFT showed better responses $(p<0.01)$ for WG and AFC than RAS. The effect of culture demonstrated that tilapia in polyculture had superior $(p<0.01) \mathrm{WG}$ and PER, when compared to monoculture. WG and S of giant freshwater prawn was superior $(p<0.01)$ in BFT compared to RAS (Table 2).

Regarding water quality, there was no difference $(p>0.05)$ for $\mathrm{T}\left({ }^{\circ} \mathrm{C}\right)$ and $\mathrm{pH}$, when compared to BFT and RAS systems. On the other hand, DO differed significantly $(p<0.05)$ (Table 3$)$.

The concentrations of TAN, $\mathrm{NO}_{2}{ }^{-}$and $\mathrm{NO}_{3}{ }^{-}$throughout the experiment are shown in Fig. 1. The levels of TAN in BFT in monoculture and polyculture oscillated during the experiment (Fig. 1a). On the other hand, $\mathrm{NO}_{2}{ }^{-}$concentrations varied between treatments and samplings with lower values in RAS compared to BFT (Fig. 1b), which in the course of the experimental period decreased the $\mathrm{NO}_{2}{ }^{-}$concentration. In BFT in monoculture and polyculture, $\mathrm{NO}_{2}{ }^{-}$at 21 days decreased for BFT in monoculture and polyculture. For RAS in monoculture and polyculture, there was a linear increasing to $\mathrm{NO}_{2}{ }^{-} . \mathrm{NO}_{3}{ }^{-}$in the BFT was higher than in the RAS up to the 21st day. From this period, the BFT in monoculture recorded lower concentrations; however, they were lower than the ones in treatments with BFT in polyculture (Fig. 1c). The accumulation of $\mathrm{NO}_{3}{ }^{-}$in the systems started at the 14 th day.

There was a difference in BFT composition over time (Table 4). The highest protein content was recorded at 15 days in monoculture $(p<0.05)$. However, there was no significant difference for EE and CF $(p>0.05)$. The SS for the different systems and cultures did not show difference $(p>0.05)$ during the experimental period (Table 4).

\section{Discussion}

Tilapia reared in BFT in monoculture and in polyculture showed superior responses to WG and AFC in comparison to RAS. Enhancement of $27.07 \%$ (monoculture) and 50.95\% (polyculture) in WG was observed for tilapia in BFT, when compared to RAS. These results corroborated with those obtained by Nootong and Pavasant (2011), who observed $21 \%$ of improvement in WG of tilapia in BFT, and those evaluated by Luo et al. (2014), with $22 \%$ of gain in WG in BFT compared to tilapia in RAS.

The bioflocs may have positively influenced the WG of tilapia when compared to RAS, where the animals fed exclusively on the artificial diet. In these systems, the same experimental diet (28\% DP and $\left.3100 \mathrm{kcal} \mathrm{kg}^{-1} \mathrm{DE}\right)$ and feed management were used, highlighting the effect of bioflocs. According to Avnimelech and Kochba (2009) the ability of tilapia to consume bioflocs can reach about $25 \%$ of the protein ingested. Thus, the best AFC results from both monoculture and polyculture confirmed the bioflocs contribution as complementary natural feed for Nile tilapia, especially the bioflocs protein fraction (Moreno-Arias et al. 2018).

PER is influenced by the quantity and quality of the protein in the diets. The nutritional quality of the bioflocs reflect the great varieties of microorganisms such as phytoplankton, bacteria, rotifers, copepods and protozoa (Crab et al. 2010; Emerenciano et al. 2013; Ray et al. 2018), providing high protein content and 


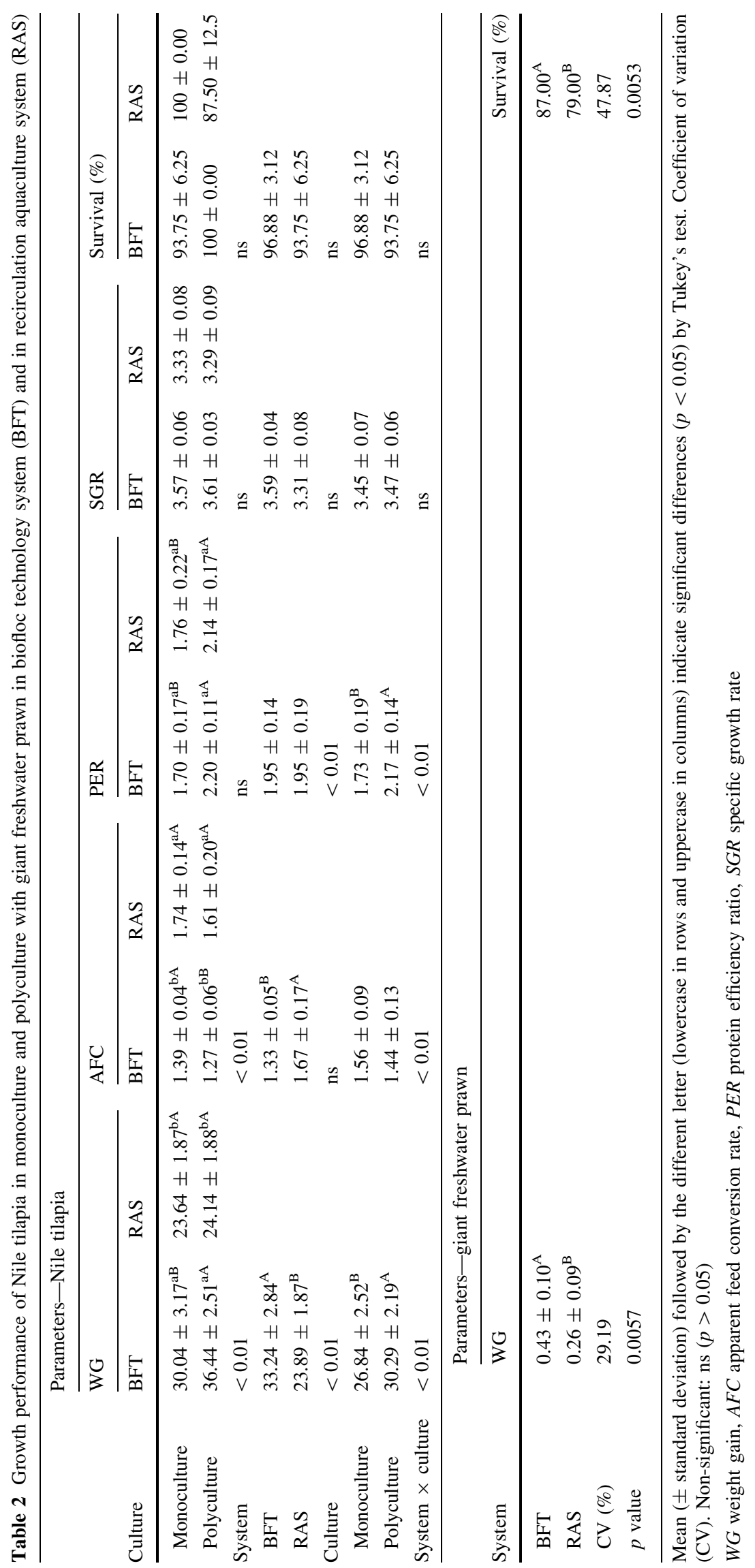


Table 3 Temperature, $\mathrm{pH}$ and dissolved oxygen in different cultures (monoculture and polyculture) and systems (BFT and RAS)

\begin{tabular}{lccccrr}
\hline Variable & \multicolumn{1}{l}{ BFTm } & \multicolumn{1}{c}{ BFTp } & \multicolumn{1}{l}{ RASm } & RASp & CV $(\%)$ & $p$ value \\
\hline $\mathrm{T}\left({ }^{\circ} \mathrm{C}\right)$ & $26.02 \pm 0.73$ & $26.27 \pm 0.46$ & $26.25 \pm 0.66$ & $25.84 \pm 0.54$ & 2.33 & 0.7256 \\
$\mathrm{pH}$ & $7.29 \pm 0.11$ & $7.32 \pm 0.03$ & $7.41 \pm 0.04$ & $7.29 \pm 0.09$ & 1.06 & 0.1221 \\
$\mathrm{DO}\left(\mathrm{mg} \mathrm{L}^{-1}\right)$ & $5.23 \pm 0.26^{\mathrm{b}}$ & $5.20 \pm 0.03^{\mathrm{b}}$ & $5.37 \pm 0.15^{\mathrm{ab}}$ & $5.61 \pm 0.19^{\mathrm{a}}$ & 3.34 & 0.0269 \\
$\mathrm{TAN}\left(\mathrm{mg} \mathrm{L}^{-1}\right)$ & $0.24 \pm 0.90$ & $0.21 \pm 0.02$ & $0.30 \pm 0.12$ & $0.23 \pm 0.11$ & 35.52 & 0.2510 \\
$\mathrm{NO}_{2}{ }^{-}\left(\mathrm{mg} \mathrm{L}^{-1}\right)$ & $0.47 \pm 0.13$ & $0.76 \pm 0.19$ & $0.38 \pm 0.15$ & $0.40 \pm 0.08$ & 29.69 & 0.7330 \\
$\mathrm{NO}_{3}{ }^{-}\left(\mathrm{mg} \mathrm{L}^{-1}\right)$ & $4.77 \pm 1.24$ & $5.50 \pm 2.52$ & $5.21 \pm 1.07$ & $4.29 \pm 0.52$ & 28.14 & 0.9486
\end{tabular}

Mean ( \pm standard deviation) followed by different letters in the same row differ by Tukey's test $(p<0.05)$

BFTm biofloc technology in monoculture, BFTp biofloc technology in polyculture, RASm recirculation aquaculture system in monoculture, $R A S p$ recirculation aquaculture system in polyculture. $T$ temperature, $D O$ dissolved oxygen, TAN total ammonia nitrogen, nitrite $\left(\mathrm{NO}_{2}{ }^{-}\right)$, nitrate $\left(\mathrm{NO}_{3}{ }^{-}\right), C V$ coefficient of variation

adequate balance between amino acids, fatty acids, minerals and vitamins (Sousa et al. 2019). Consequently, the best PER of tilapia in BFT is a consequence of bioflocs consumption that show good nutritional profile.

Prawn cultured in BFT showed WG 65.4\% superior in comparison to RAS. According to Souza et al. (2009), freshwater prawn Macrobrachium amazonicum (Heller 1862) did not influence the growth of Nile tilapia in polyculture in RAS. However, in the present study, polyculture with tilapia and giant freshwater prawn boosted the growth performance both BFT and RAS for these two species. These results corroborated to the obtained by Crab et al. (2012), who observed best growth performance and feed efficiency in BFT in polyculture of fish and prawn due to the supply of natural feed with high biological value.

Similar to tilapia responses, the difference in WG for prawns in the present study can be associated with the use of bioflocs as supplementary feed. According to Kuhn et al. (2010), the bioflocs may replace, partially or totally, fishmeal in diets for the Pacific white shrimp, Litopenaeus vannamei (Boone 1931). On the other hand, Burford et al. (2004) observed a range between 18 and 29\% of nitrogen consumed by Pacific white shrimp originated from BFT. Furthermore, according to Ballester et al. (2017), the bacterial communities that make up the bioflocs may provide better responses for disease resistance and survival, which can explain the superior S (87\%) in BFT in comparison to RAS (79\%).

The water quality variables were within the normal range tilapia and freshwater prawn, as recommended by Popma and Lovshin (1995) and New et al. (2010), respectively. In BFT in monoculture and in BFT in polyculture, DO values were lower than in RAS in monoculture and in RAS in polyculture, but they remained throughout the period above $5 \mathrm{mg} \mathrm{L}^{-1}$. According to Fang et al. (2018), low concentrations of DO in BFT can occur due to respiration of microorganisms, fish and prawns. Therefore, it is known that DO values below $4 \mathrm{mg} \mathrm{L}^{-1}$ can negatively affect the metabolic activity of heterotrophic bacteria, which did not occur in the present study and did not affect the animals performance and the development of the bioflocs.

Nitrogen compounds oscillated during the experimental period, although they did not differ statistically. TAN concentration was controlled by supplementary source of carbon, which modulates the heterotrophic bacteria growing through $\mathrm{C} / \mathrm{N}$ ratio (Schneider et al. 2005). Increase in $\mathrm{NO}_{3}{ }^{-}$and decreasing $\mathrm{NO}_{2}{ }^{-}$due to the nitrification process occurred in BFT (Wasielesky et al. 2013) and in RAS (Timmons and Ebeling 2007; Sesuk et al. 2009).

The bromatological composition of the bioflocs (monoculture) presented a significant variation for PB in relation to the experimental period and for MM in relation to the initial and final period between the cultures (mono- and polyculture). The results of the present study are similar to those obtained by Azim and Little (2008), for MM (12\%); however, the value for PB was higher (38\%) than the ones found in this study (23\%). These variations may occur because the composition of the bioflocs are related to several factors, such as the source of carbon added to the growth development of some microbial communities, diets, animals and different sampling periods (Lobato et al. 2019; Sajali et al. 2019).

The volume of SS concentration did not present statistical difference. The linear growth of the flocs volume was observed by Widanarni et al. (2012), when evaluating the application of bioflocs and water quality in the production of tilapia reared at different densities. The SS values obtained in the present study were lower than those suggested (40-60 $\mathrm{ml} \mathrm{L}^{-1}$ ) by De-Schryver et al. (2008). 

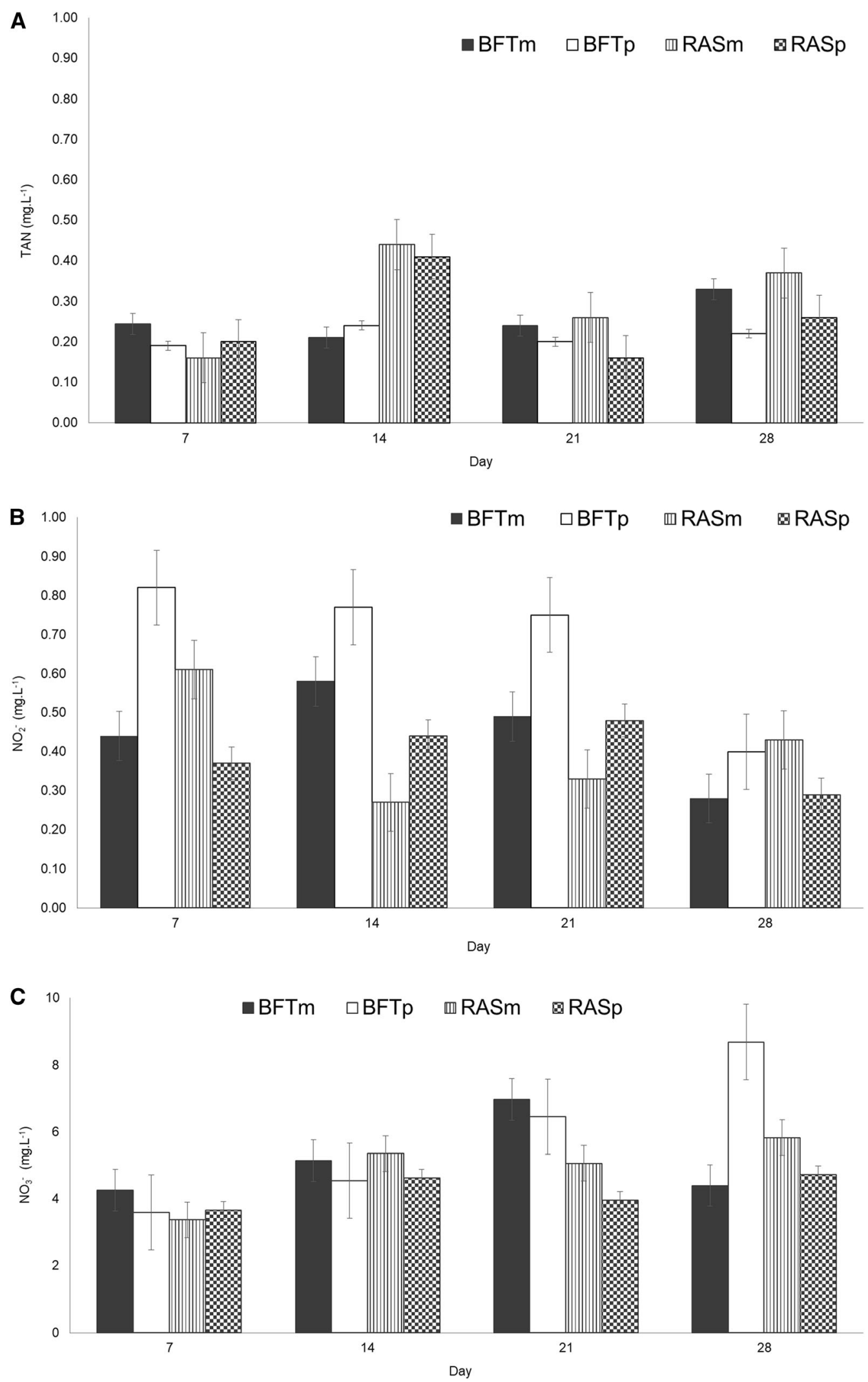

Fig. 1 Mean values ( \pm standard deviation) of total ammonia nitrogen (TAN), nitrite $\left(\mathrm{NO}_{2}{ }^{-}\right)$and nitrate $\left(\mathrm{NO}_{3}{ }^{-}\right)$throughout the experimental testing in biofloc technology in monoculture (BFTm); biofloc technology in polyculture (BFTp); recirculation aquaculture system in monoculture (RASm); and recirculation aquaculture system in polyculture (RASp) 
Table 4 Chemical composition and volume of bioflocs during experimental period

\begin{tabular}{|c|c|c|c|c|c|c|}
\hline Parameter & $\begin{array}{l}\text { Monoculture } \\
15 \text { days }\end{array}$ & $\begin{array}{l}\text { Polyculture } \\
15 \text { days }\end{array}$ & $\begin{array}{l}\text { Monoculture } \\
30 \text { days }\end{array}$ & $\begin{array}{l}\text { Polyculture } \\
30 \text { days }\end{array}$ & $\mathrm{CV}(\%)$ & $p$ value \\
\hline $\mathrm{CP}(\%)$ & $24.22 \pm 0.12^{\mathrm{a}}$ & $23.21 \pm 036^{\mathrm{b}}$ & $22.53 \pm 0.13^{\mathrm{b}}$ & $23.21 \pm 0.28^{\mathrm{b}}$ & 1.03 & 0.0099 \\
\hline $\mathrm{EE}(\%)$ & $3.16 \pm 0.34^{\mathrm{a}}$ & $4.55 \pm 0.62^{\mathrm{a}}$ & $3.23 \pm 0.13^{\mathrm{a}}$ & $3.67 \pm 0.46^{\mathrm{a}}$ & 11.82 & 0.2297 \\
\hline $\mathrm{CF}(\%)$ & $5.31 \pm 0.40^{\mathrm{a}}$ & $5.89 \pm 0.71^{\mathrm{a}}$ & $5.6 \pm 0.59^{\mathrm{a}}$ & $5.23 \pm 0.33^{\mathrm{a}}$ & 8.14 & 0.3898 \\
\hline MM (\%) & $14.01 \pm 0.03^{\mathrm{ab}}$ & $11.85 \pm 1.95^{\mathrm{b}}$ & $15.80 \pm 0.14^{\mathrm{a}}$ & $12.33 \pm 0.45^{\mathrm{b}}$ & 4.47 & 0.0087 \\
\hline \multicolumn{7}{|c|}{ Volume and concentration } \\
\hline $\mathrm{SS}\left(\mathrm{mL} \mathrm{L}^{-1}\right)$ & $9.13 \pm 2.72^{\mathrm{a}}$ & $7.00 \pm 3.56^{\mathrm{a}}$ & $11.75 \pm 2.22^{\mathrm{a}}$ & $8.38 \pm 5.59^{\mathrm{a}}$ & 41.36 & 0.3744 \\
\hline
\end{tabular}

Mean ( \pm standard deviation) followed by different letters in the same row differ by Tukey's test $(p<0.05)$. Coefficient of variation $(\mathrm{CV})$

$C P$ Crude protein, $E E$ ether extract, $C F$ crude fiber, $M M$ mineral matter, $S S$ settleable solids

The use of the BFT, besides enabling the maintenance of water quality, reduces the use of water resources and environmental impact (Azim and Little 2008), generates greater economy and productivity in relation to RAS (García-Ríos et al. 2019) and the reduction of PB in the diet, since the microbial flocs can reach the PB level of $50 \%$, a fact that can reduce feed expenses by up to $20 \%$ (Pérez-Fuentes et al. 2018).

In general, comparing the systems, fish in BFT showed better growth responses than in RAS. Between the cultures, fish in polyculture had better growth performance than in monoculture. Considering prawn in BFT system, an improvement in WG and S was obtained when compared to RAS. Thus, polyculture in BFT is a potential alternative, since the bioflocs can contribute to better WG responses for tilapia and prawn when compared to RAS, due to its ability to capture the particles flocs and microorganisms in suspension. However, studies with polyculture (tilapia and prawn) in BFT in field conditions must be conducted for commercial scale validation and to provide practical information for fish and prawn farmers. Furthermore, polyculture in BFT also allows the reduction of feed costs and the higher productivity per area, and can result in greater profitability, where fish is the main product and prawn is a complementary product of high benefit that should be encouraged to reach a responsible culture with reduction of environmental impact, through integrated production.

The data showed a positive interaction between culture (monoculture and polyculture) and systems (BFT and RAS). BFT provides better growth performance in monoculture for Nile tilapia and in polyculture with giant freshwater prawn comparing to RAS, improving the growth of both species. Polyculture of Nile tilapia and giant freshwater prawn in BFT can be considered a potential alternative as an eco-friendly aquaculture model.

Acknowledgements To Empresa Brasileira de Pesquisa Agropecuária (Embrapa Project $\mathrm{n}^{\circ}$ 03.13.09.007.00.), for financial support and Coordenação de Aperfeiçoamento de Pessoal de Nível Superior (CAPES/Brazil) for scholarships to Phillipe T. L. Barbosa.

\section{Compliance with ethical standards}

Conflict of interest The authors declare that they have no conflict of interest.

Open Access This article is distributed under the terms of the Creative Commons Attribution 4.0 International License (http:// creativecommons.org/licenses/by/4.0/), which permits unrestricted use, distribution, and reproduction in any medium, provided you give appropriate credit to the original author(s) and the source, provide a link to the Creative Commons license, and indicate if changes were made.

\section{References}

AOAC (2000) Official methods of analysis, 17th edn. Association of Official Analytical Chemists, Gaithersburg

Avnimelech Y (2007) Feeding with microbial flocs by tilapia in minimal discharge bio flocs technology ponds. Aquaculture 264:140-147. https://doi.org/10.1016/j.aquaculture.2006.11.025

Avnimelech Y (2009) Biofloc technology a practical guidebook. The World Aquaculture Society, Baton Rouge, p 182 
Avnimelech Y, Kochba M (2009) Evaluation of nitrogen uptake and excretion by tilapia in bio floc tanks, using ${ }^{15} \mathrm{~N}$ tracing. Aquaculture 287:163-168. https://doi.org/10.1016/j.aquaculture.2008.10.009

Azim ME, Little DC (2008) The biofloc technology (BFT) in indoor tanks: water quality, biofloc composition, and growth and welfare of Nile tilapia Oreochromis niloticus. Aquaculture 283:29-35. https://doi.org/10.1016/j.aquaculture.2008.06.036

Ballester ELC, Marzarotto SA, Castro CS, Frozza A, Pastore I, Abreu PC (2017) Productive performance of juvenile freshwater prawns Macrobrachium rosenbergii in biofloc system. Aquac Res 48:4748-4755. https://doi.org/10.1111/are.13296

Bregnballe J (2015) A guide to recirculation aquaculture: an introduction to the new environmentally friendly and highly productive closed fish farming systems. FAO and EUROFISH International Organization, Copenhagen

Burford MA, Thompson PJ, Mcintosh RP, Bauman RH, Pearson DC (2004) The contribution of flocculated material to shrimp (Litopenaeus vannamei) nutrition in a high-intensity, zero-exchange system. Aquaculture 232:525-537. https://doi.org/10. 1016/S0044-8486(03)00541-6

Crab R, Chielens B, Wille M, Bossier P, Verstraete W (2010) The effect of different carbon sources on the nutritional value of bioflocs, a feed for Macrobrachium rosenbergii post larvae. Aquac Res 41:559-567. https://doi.org/10.1111/j.1365-2109. 2009.02353.x

Crab R, Defoirdt T, Bossier P, Verstraete W (2012) Biofloc technology in aquaculture: beneficial effects and future challenges. Aquaculture 356:351-356. https://doi.org/10.1016/j.aquaculture.2012.04.046

De-Schryver P, Crab R, Defoirdt T (2008) The basics of bio flocs technology: the added value for aquaculture. Aquaculture 277:125-137. https://doi.org/10.1016/j.aquaculture.2008.02.019

Emerenciano M, Gaxiola G, Cuzon G (2013) Biofloc technology (BFT): a review for aquaculture application and animal food industry. In: Matovic MD (ed) Biomass now—cultivation and utilization, 12th edn. In Tech, Rijeka. https://doi.org/10.5772/ 53902

Fang Y, Chen X, Hu Z, Liu D, Gao H, Nie L (2018) Effects of hydraulic retention time on the performance of algal-bacterialbased aquaponics (AA): focusing on nitrogen and oxygen distribution. Appl Microbiol Biotechnol 102:9843-9855. https:// doi.org/10.1007/s00253-018-9338-1

FAO (2018a) The State of World Fisheries and Aquaculture 2018-meeting the sustainable development goals. License: CC BYNC-SA 3.0 IGO, Rome

FAO (2018b) Fisheries and agriculture organization of the United Nations. Fact Sheets: Macrobrachium rosenbergii (De Man, 1879). In Cultured Aquatic Species Information Programme, Fisheries and Aquaculture Department, FAO, Rome. http:// www.fao.org/fishery/culturedspecies/Macrobrachium_rosenbergii/en. Accessed 11 Feb 2019

Furuya WM (2010) Tabelas brasileiras para nutrição de tilápias. GFM, Toledo, p 100

Gao F, Liao S, Liu S, Bai H, Wang A, Ye J (2019) The combination use of Candida tropicalis HH8 and Pseudomonas stutzeri LZX301 on nitrogen removal, biofloc formation and microbial communities in aquaculture. Aquaculture 500:50-56. https:// doi.org/10.1016/j.aquaculture.2018.09.041

García-Pérez A, Alston DE, Cortés-Maldonado R (2000) Growth, survival, yield and size distributions of freshwater prawn Macrobrachium rosenbergii and tilapia Oreochromis niloticus in polyculture and monoculture systems in Puerto Rico. J World Aquacult Soc 31:446-451. https://doi.org/10.1111/j.1749-7345.2000.tb00894.x

García-Ríos L, Miranda-Baeza A, Coelho-Emerenciano MG, Huerta-Rábago JA, Osuna-Amarillas P (2019) Biofloc technology (BFT) applied to tilapia fingerlings production using different carbon sources: emphasis on commercial applications. Aquaculture 502:26-31. https://doi.org/10.1016/j.aquaculture.2018.11.057

Grassi TLM, Espírito-Santo EF, Siqueira-Marcos MT, Cavazzana JF, Oliveira DL, Bossolani ILC, Ponsano EHG (2016) Bacterial pigment for Nile tilapia feeding. Aquac Int 24:647-660. https://doi.org/10.1007/s10499-015-9955-y

Haque MR, Islam MA, Rahman MM, Shirin MF, Wahab MA, Azim ME (2015) Effects of C/N ratio and periphyton substrates on pond ecology and production performance in giant freshwater prawn Macrobrachium rosenbergii (De Man, 1879) and tilapia Oreochromis niloticus (Linnaeus, 1758) polyculture system. Aquac Res 46:1139-1155. https://doi.org/10.1111/are.12270

Haque MR, Islam MA, Khatun Z, Hossain MA, Wahab MA (2018) Effects of stocking densities of tilapia Oreochromis niloticus (Linnaeus, 1758) with the inclusion of silver carp Hypophthalmichthys molitrix (Valenciennes, 1844) in C/N-CP prawn Macrobrachium rosenbergii (De Man, 1879) culture pond. Aquac Int 26:523-541. https://doi.org/10.1007/s10499-017-02298

Hossain A, Islam MS (2006) Optimization of stocking density of freshwater prawn Macrobrachium rosenbergii (De man) in carp polyculture in Bangladesh. Aquac Res 37:994-1000. https://doi.org/10.1111/j.1365-2109.2006.01518.x

Kuhn DD, Lawrence AL, Boardman GD, Patnaik S, Marsh L, Flick GJ Jr (2010) Evaluation of two types of bioflocs derived from biological treatment of fish effluent as feed ingredients for Pacific white shrimp, Litopenaeus vannamei. Aquaculture 303:28-33. https://doi.org/10.1016/j.aquaculture.2010.03.001

Li D, Dong S (2000) Summary of studies on closed-polyculture of penaeid shrimp with fishes and moluscans. Chin J Oceanol Limnol 18:61-66. https://doi.org/10.1007/BF02842543

Lobato OSC, Ribeiro FAS, Miranda-Baeza A, Emerenciano MGC (2019) Production performance of Litopenaeus vannamei (Boone, 1931) fed with different dietary levels of tilapia processing waste silage reared in biofloc system using two carbon sources. Aquaculture 501:515-518. https://doi.org/10.1016/j.aquaculture.2018.12.006

Luo G, Gao Q, Wang C, Liu W, Sun D, Li L, Tan H (2014) Growth, digestive activity, welfare, and partial cost effectiveness of genetically improved farmed tilapia (Oreochromis niloticus) cultured in a recirculating aquaculture system and an indoor biofloc system. Aquaculture 422:1-7. https://doi.org/10.1016/j.aquaculture.2013.11.023

Moreno-Arias A, López Elías JA, Martínez Córdova LR, Ramírez Suárez JC, Carvallo Ruiz MG, García Sánchez G, Lugo Sánchez ME, Miranda Baeza A (2018) Effect of fishmeal replacement with a vegetable protein mixture on the amino acid and fatty acid profiles of diets, biofloc and shrimp cultured in BFT system. Aquaculture 483:53-62. https://doi.org/10.1016/j. aquaculture.2017.10.011 
New MB, Valenti WC, Tidwell JH, D'Abramo LR, Kutty MN (2010) History and global status of freshwater prawn farming. In: Freshwater prawns: biology and farming, 1st edn. pp 1-9. https://doi.org/10.1002/9781444314649.ch1

Nootong K, Pavasant P (2011) Effects of organic carbon addition in controlling inorganic nitrogen concentrations in a biofloc system. J World Aquac Soc 42:339-346. https://doi.org/10.1111/j.1749-7345.2011.00472.x

NRC (1993) Nutrient requirements of fish. National Research Council. The National Academies Press, Washington. https://doi. org/10.17226/2115

NRC (2011) Nutrient requirements of fish and shrimp. National Research Council. The National Academies Press, Washington. https://doi.org/10.17226/13039

Pérez-Fuentes JA, Pérez Rostro CI, Hernández Vergara MP, Monroy Dosta MC (2018) Variation of the bacterial composition of biofloc and the intestine of Nile tilapia Oreochromis niloticus, cultivated using biofloc technology, supplied different feed rations. Aquac Res 49:3658-3668. https://doi.org/10.1111/are.13834

Poli MA, Legarda EC, Lorenzo MA, Martins MA, Vieira FN (2019) Pacific white shrimp and Nile tilapia integrated in a biofloc system under different fish-stocking densities. Aquaculture 498:83-89. https://doi.org/10.1016/j.aquaculture.2018.08.045

Popma TJ, Lovshin LL (1995) Worldwide prospects for commercial production of Tilapia. Aquaculture production manual. Auburn University, Alabama 36849 International Center for Aquaculture and Aquatic Environments, p 42. http://www.aces. edu/dept/fisheries/aquaculture/docs/worldtilapia.pdf. Accessed 08 Oct 2018

Ray AJ, Leffer JW, Browdy C (2018) The effects of a conventional feed versus a fish-free feed and biofloc management on the nutritional and human sensory characteristics of shrimp (Litopenaeus vannamei). Aquac Int 26:1-17. https://doi.org/10.1007/ s10499-018-0321-8

Robinson G, MacTavish T, Savage C, Caldwell GS, Jones CLW, Probyn T, Eyre BD, Stead SM (2018) Carbon amendment stimulates benthic nitrogen cycling during the bioremediation of particulate aquaculture waste. Biogeosciences 15:1863-1878. https://doi.org/10.5194/bg-15-1863-2018

Robinson G, Caldwell GS, Jones CLW, Stead SM (2019) The effect of resource quality on the growth of Holothuria scabra during aquaculture waste bioremediation. Aquaculture 499:101-108. https://doi.org/10.1016/j.aquaculture.2018.09.024

Rohmana D, Surawidjaja EH, Sukenda S, Ekasari J (2015) Water quality and production performance of catfish-prawn co-culture with organic carbon source addition. Aquac Int 23:267-276. https://doi.org/10.1007/s10499-014-9814-2

Sajali USBA, Atkinson NL, Desbois AP, Little DC, Murray FJ, Shinn AP (2019) Prophylactic properties of biofloc- or Nile tilapia-conditioned water against Vibrio parahaemolyticus infection of whiteleg shrimp (Penaeus vannamei). Aquaculture 498:496-502. https://doi.org/10.1016/j.aquaculture.2018.09.002

Samocha TM, Patnaik S, Speed M, Ali AM, Burger JM, Almeida RV, Ayub Z, Harisanto M, Horowitz A, Brock DL (2007) Use of molasses as carbon source in limited discharge nursery and grow out systems for Litopenaeus vannamei. Aquac Eng 36:184-191. https://doi.org/10.1016/j.aquaeng.2006.10.004

Santos MJM, Valenti WC (2002) Production of Nile tilapia Oreochromis niloticus and freshwater prawn Macrobrachium rosenbergii stocked at different densities in polyculture systems in Brazil. J World Aquac Soc 33:369-376. https://doi.org/10. 1111/j.1749-7345.2002.tb00513.x

Schneider O, Sereti V, Eding EH, Verreth JAJ (2005) Analysis of nutrient flows in integrated intensive aquaculture systems. Aquacult Eng 32(3-4):379-401. https://doi.org/10.1016/j.aquaeng.2004.09.001

Schreier H, Mirzoyan N, Saito K (2010) Microbial diversity of biological filters in recirculating aquaculture systems. Curr Opin Chem Biol 21(3):318-325. https://doi.org/10.1016/j.copbio.2010.03.011

Schveitzer R, Arantes R, Costódio PFS, Santo CME, Arana LV, Seiffert WQ, Andreatta ER (2013) Effect of different biofloc levels on microbial activity, water quality and performance of Litopenaeus vannamei in a tank system operated with no water exchange. Aquac Eng 56:59-70. https://doi.org/10.1016/j.aquaeng.2013.04.006

Sesuk T, Powtongsook S, Nootong K (2009) Inorganic nitrogen control in a novel zero water exchanged aquaculture system integrated with airlift submerged fibrous nitrifying biofilters. Bioresour Technol 100:2088-2094. https://doi.org/10.1016/j. biortech.2008.10.027

Sousa AA, Pinho SM, Rombenso AN, Mello GL, Emerenciano MGC (2019) Pizzeria by-product: a complementary feed source for Nile tilapia (Oreochromis niloticus) raised in biofloc technology? Aquaculture 501:359-367. https://doi.org/10.1016/j. aquaculture.2018.11.055

Souza BE, Stringuetta LL, Bordignon AC, Bohnenberger L, Boscolo WR, Feiden A (2009) Polyculture of fresh water shrimp Macrobrachium amazonicum (Heller, 1862) with Nile tilapia (Oreochromis niloticus) feeding with ration pelleted and mashed. Semina: Ciênc Agrár 30:225-232. https://doi.org/10.5433/1679-0359.2009v30n1p225

Tacon AGJ, Hasan MR, Metian M (2011) Demand and supply of feed ingredients for farmed fish and crustaceans: trends and prospects. FAO Food and Agriculture Organization of the United Nations. Fisheries and Aquaculture Technical Paper n.564. Rome, p 87. ISSN 2070-7010

Timmons MB, Ebeling JM (2007) Recirculating aquaculture, 3rd edn. NRAC Publication, 948, 01-07

Uddin S, Ekram-Ul-Azim M, Wahab A, Verdegem MC (2006) The potential of mixed culture of genetically improved farmed tilapia (Oreochromis niloticus) and freshwater giant prawn (Macrobrachium rosenbergii) in periphyton-based systems. Aquac Res 37:241-247. https://doi.org/10.1111/j.1365-2109.2005.01424.x

Vargas-Albores F, Martínez-Córdova LR, Gollas-Galván T, Garibay-Valdez E, Emerenciano MGC, Lago-Leston A, MazorraManzano M, Martínez-Porchas M (2019) Inferring the functional properties of bacterial communities in shrimp-culture bioflocs produced with amaranth and wheat seeds as fouler promoters. Aquaculture 500:107-117. https://doi.org/10.1016/j. aquaculture.2018.10.005

Wasielesky W, Krummenauer D, Lara G, Fóes G, Poersch L (2013) Cultivo de camarões em Sistema de bioflocos: Realidades e perspectivas. ABCC 15:30-36 
Widanarni W, Ekasari J, Maryam S (2012) Evaluation of Biofloc technology application on water quality and production performance of red tilapia Oreochromis sp. cultured at different stocking densities. HAYATI J Biosci 19:73-80. https://doi. org/10.4308/hjb.19.2.73

Zimmermann S, New MB (2000) Grow out systems-polyculture and integrated culture. In: New MB, Valenti WC (eds) Freshwater prawn culture: the farming of Macrobrachium rosenbergii. Blackwell Science, Oxford, pp 187-202

\section{Publisher's Note}

Springer Nature remains neutral with regard to jurisdictional claims in published maps and institutional affiliations. 